\title{
Transthyretin familial amyloid polyneuropathy (TTR-FAP) in Mallorca: a comparison between late- and early-onset disease
}

\author{
Manuel Raya-Cruz ${ }^{1 *}$, Juan Buades-Reines ${ }^{1}$, Cristina Gallego-Lezaun ${ }^{1}$, Ignacio Ferullo', Tomas Ripoll-Vera², \\ Mercedes Uson-Martín ${ }^{3}$, Hernan Andreu-Serra ${ }^{4}$ \\ From First European Congress on Hereditary ATTR amyloidosis \\ Paris, France. 2-3 November 2015
}

\section{Background}

The age of onset (AO) of familial transthyretin-mediated amyloidosis with polyneuropathy (TTR-FAP) is known to vary between populations, with differing characteristics reported according to $\mathrm{AO}$ in endemic/non-endemic foci.

\section{Methods}

This was a retrospective study of patients with early $\mathrm{AO}$ ( $<50$ years) and late AO ( $\geq 50$ years) TTR-FAP at our community center in Mallorca. Data were collected on patient demographics, clinical disease manifestation, and physical symptoms.

\section{Results}

A total of 95 patients were analyzed, with mean followup of 9.39 years from diagnosis. The early AO group included 53 patients (33 male) and the late AO group included 42 patients (21 male). Neurologic involvement was the most common initial symptom, although was significantly more frequent in the late $\mathrm{AO}$ versus early AO group $(\mathrm{p}=0.015)$. Autonomic involvement was observed in $26 \%$ of patients in the early AO group, but was rarely observed in the late AO group (5\%). During follow-up, cardiologic symptoms, renal involvement, and ophthalmologic symptoms were significantly more common in the late AO group $(\mathrm{p}<0.05)$.

\section{Conclusions}

This retrospective study demonstrates the variation in disease presentation and progression according to $\mathrm{AO}$

\footnotetext{
${ }^{1}$ Son Llàtzer Hospital, Internal Medicine, 07198, Palma de Mallorca, Spain
} Full list of author information is available at the end of the article of TTR-FAP at our Mallorcan center. These data will inform diagnosis and monitoring of disease, and guide effective treatment choices.

\section{Authors' details \\ 'Son Llàtzer Hospital, Internal Medicine, 07198, Palma de Mallorca, Spain. ${ }^{2}$ Son Llàtzer Hospital, Cardiology, 07198, Palma de Mallorca, Spain. ${ }^{3}$ Son Llàtzer Hospital, Neurology, 07198, Palma de Mallorca, Spain. ${ }^{4}$ Son Llàtzer Hospital, Digestive, 07198, Palma de Mallorca, Spain.}

Published: 2 November 2015

doi:10.1186/1750-1172-10-S1-P29

Cite this article as: Raya-Cruz et al:: Transthyretin familial amyloid polyneuropathy (TTR-FAP) in Mallorca: a comparison between late- and early-onset disease. Orphanet Journal of Rare Diseases 2015 10(Suppl 1): P29.
Submit your next manuscript to BioMed Central and take full advantage of:

- Convenient online submission

- Thorough peer review

- No space constraints or color figure charges

- Immediate publication on acceptance

- Inclusion in PubMed, CAS, Scopus and Google Scholar

- Research which is freely available for redistribution

Submit your manuscript at www.biomedcentral.com/submit
() Biomed Central 